\title{
Assessment of microbial and level of Cadmium, Chromium and Lead contamination on drinking water refilling station in Bungus Teluk Kabung, West Sumatera, Indonesia
}

\author{
Azimatur Rahmi ${ }^{1}$, Rahma Yulia ${ }^{1}$, Asmaul Husna ${ }^{1}$, and Amelia Amir ${ }^{2, *}$ \\ ${ }^{1}$ Faculty of Pharmacy, Mohammad Natsir University, Jl. Tan Malaka, Bukit Cangang Kayu Ramang, kec. \\ Guguk Panjang, Bukittinggi, Sumatera Barat, 26138, Indonesia \\ ${ }^{2}$ STIKES Merangin, Jln. Bangko-Kerinci Km. 6 Kungkai, Kec. Bangko, Merangin, Jambi, Indonesia
}

\begin{abstract}
Refill drinking water is a choice of drinking water, especially for the middle-income community due to the convenience and affordable price. Many studies in Indonesia reported that drinking water from drinking water refilling stations is less safe or contaminated by coliform. This study assessed the microbial and level of several heavy metals (Cadmium, chromium, and Lead) contamination on refill drinking water from drinking water refilling station in Bungus Teluk Kabung West Sumatera, Indonesia. It found that Cadmium, Chromium, and Lead were detected in all samples. Still, none of their levels exceed the maximum permissible limits based on the guideline value on Ministry of Health Republic of Indonesia number 492/MENKES/PER/IV/2010. Lead was found as the highest amount in sample B and then Chromium in sample A with values of $0.367 \mathrm{ppb}$ and $0.143 \mathrm{ppb}$. The microbial contamination presence in all three refill drinking water samples with the total coliform was 28,15 , and $240 \mathrm{MPN}$ per $100 \mathrm{ml}$ for samples A, B, and C. Sample C has the highest microbial risk compare to A and B. The presence of E. Coli was also confirmed for all samples, and the metallic sheen identified it in all culture samples. Because the standard of the microbial parameter must be zero for coliform and E. Coli, these results revealed that all three refill drinking water samples from drinking water refilling stations Bungus Teluk Kabung are not eligible for direct consumption and could harm human health. The proper water treatment process or change in raw water sources need to be considered in the future. Inspection and monitoring from the health authority should be scheduled regularly to protect the consumers.
\end{abstract}

Keywords: Assessment; Water Quality; Drinking Water Refilling Station; Lead; Cadmium; Chromium; Coliform.

\section{Introduction}

Drinking water is a basic need for human life. To date, refill drinking water from a drinking water refilling station (DWRS) is an alternative for daily drinking water, especially for people with no access to a water supply network in developing countries such as Indonesia. Affordable prices and convenience become the reason for the middle-income community to choose to refill drinking water ${ }^{1-3}$. In West Sumatera, the consumers do not need to bring their water containers to the refilling stations because mostly the owners give the service by picking and delivering to the consumer's home. The price is also lower than the branded refill drinking water or bottled water. Currently, the price per gallon (19 liters) is around 5-7 thousand rupiahs. Whereas the engraved refill drinking water around 20 thousand rupiahs. Due to the lower price of refill drinking water, assessment plays a vital role in verifying the safety of the refill drinking water itself.
In 2010, the Ministry of Health Republic of Indonesia had issued regulation number 492/MENKES/PER/ IV/2010 about the guideline for drinking water quality. In this regulation, several standards for drinking water quality based on physical (smell, color, total dissolved solids, turbidity, taste, and temperature), chemical (organic, inorganic, pesticide, and disinfectant), microbiological (total coliform and Escherichia coli) and radioactivity (gross alpha and gross beta activity) parameters. Those parameters are in the World Health Organization (WHO) guidelines for drinking water quality ${ }^{4-5}$. Another regulation from the Ministry of Health Republic of Indonesia is regulation number 43 about hygiene and sanitation of DWRS. The owners of DWRS must have the license for the business and need to fulfill several requirements related to hygiene and sanitation. The health authority inspected the compliance of sanitation and hygiene requirements at least twice a year ${ }^{6}$. 
Nevertheless, many studies in Indonesia found that the water quality of refill drinking water did not meet the health standard requirements based on regulation number 492/MENKES/PER/IV/2010. Several previous studies in some Indonesia, especially reported about microbial contamination, showed that the refill drinking water was less safe or contaminated with E. coli or coliform bacteria ${ }^{2,3,7-11}$. Maximum permissible limit of verification microbial quality for all water directly intended for drinking must not be detectable in any $100 \mathrm{ml}$ samples ${ }^{5}$. Likewise, the regulation on Minister of Health Republic of Indonesia number 492/Menkes/Per/IV/2010, the microbiological parameter is an obligatory parameter. The maximum standard limit for both E. Coli and total coliform are zero in $100 \mathrm{ml}$ water sample ${ }^{4}$.

It found a few studies of heavy metals contamination in refill drinking water in Indonesia. Ismayanti N. A. et al. reported one of three refill drinking water from DWRS in the Islam University of Indonesia in Yogyakarta contaminated by Cadmium and Lead with the level contamination $0.0083 \mathrm{mg} / \mathrm{L} \quad 0.21 \mathrm{mg} / \mathrm{L}$, respectively. These values exceed the guideline values based on the regulation number 492/MENKES/PER/IV/2010, where permissible values for Cadmium and Lead are $0.003 \mathrm{mg} / \mathrm{L}$ and $0.01 \mathrm{mg} / \mathrm{L}$, respectively ${ }^{12}$. Another study in Pekanbaru reported a high level of Lead and cadmium contamination to the raw water source of refill drinking water and refill drinking water itself. All samples from five DWRS in five different areas in Pekanbaru contained Lead and Cadmium. The raw water source for refill drinking water of those five DWRS from groundwater near each DWRS. The level of Cadmium varied from 0.22 to $0.54 \mathrm{ppm}$, and the Lead level varied from 0.11 to $1.87 \mathrm{ppm}$. Location of raw water source in the industrial and urban area becomes the reason of the contamination possibly occurs ${ }^{13}$.

Waterborne diseases are transmitted through water contaminated with microbes. Microbial contamination of drinking water can cause diarrhea. It threatens human health. Another contamination that may occur in drinking water is heavy metal contamination ${ }^{5}$. Heavy metal contamination in water can be caused by urbanization and industrialization. Heavy metal can bioaccumulate in human systems when it is swallowed or inhaled into the body. It can be a source of disease when excess in the human body ${ }^{14}$. Chowdhury et al. reported that human exposure to heavy metal primarily through water consumption ${ }^{15}$. Human long exposure to Cadmium is toxic for the kidney and liver. Various cancers can be associated with Cadmium exposure, such as breast, lung, prostate, nasopharynx, pancreas, and kidney cancers ${ }^{16-18}$. Several health effects of Lead exposure are high blood pressure, headache, abdominal pain, lung and stomach cancers ${ }^{18}$. Both Lead and Cadmium can also have toxic effects on the structure and function of reproductive organs ${ }^{19}$. Another public health concern of heavy metals is Chromium. Chromium is naturally distributed in the earth's crust. It is an essential macronutrient. Human-associated chromium exposure is respiratory, skin, carcinogenic, renal, hepatic, gastrointestinal, cardiovascular, hematological, reproductive and developmental, genotoxic, and mutagenic effects. Chromium (VI) appears to be much more toxic than other Chromium compounds ${ }^{20-23}$.

In 2012, Wandrivel et al. reported microbial quality of refill drinking water from DWRS in Bungus Teluk Kabung. The refill drinking water sample was from three different types of raw water sources (55,6\% from mount Talang Solok, 33,3\% from the hilly side Bungus Teluk Kabung, and 11,1\% from the regional water company or PDAM). The results showed $55,5 \%$ of refill drinking water was contaminated by coliform. It also reported $80 \%$ of samples from mount Talang raw water were contaminated. At the same time, all samples with raw water from springs in the hilly side Bungus Teluk Kabung and from PDAM were positive in microbial contamination. However, it still did not study heavy metal contamination to refill drinking water from DWRS in Bungus Teluk Kabung. Therefore, this study assessed the water quality of refill drinking water from DWRS in Bungus Teluk Kabung, a raw water source from springs in the hilly side of Bungus Teluk Kabung. It was conducted from January to February 2020. The Cadmium, Chromium, and Lead and coliform contamination levels were analyzed in the laboratory, and those results were compared with the guideline values for drinking water established by the Minister of Health Republic of Indonesia number 492/Menkes/Per/IV/2010.

\section{Materials and Methods}

\subsection{Sampling Site Description}

Bungus Teluk Kabung is one of the districts located in the coastal area of the southern part of Padang, West Sumatera, Indonesia, and covering 100.78 square kilometers. It has an average altitude of about $0-5 \mathrm{~m}$ and $<850 \mathrm{~m}$ for coastal and hilly areas ${ }^{24}$. Bungus Teluk Kabung is an industrial, agricultural, and port area. This area has long been a tourism object and as central distribution of Pertamina (oil and natural gas mining company) ${ }^{25}$. Samples for this study were collected from three DWRS located in this area. Those three DWRS used raw water sources from springs in the hilly side and distributed by pipe to the DWRS.

\subsection{Water Sampling}

Refill drinking water from three DWRS in Bungus Teluk Kabung were collected in sterile bottles. Those samples were taken from the outlet tap of refill drinking water (water after the treatment). Afterward, those samples were kept in a box and directly transported to the laboratory. It took about one hour from the sampling site to the laboratory. Those 
samples were prepared to be analyzed as soon as they arrived in the laboratory.

\subsection{Microbial Analysis ${ }^{26}$}

Microbial assessments were conducted at the Health Laboratory Agency (UPTD Balai Laboratorium Kesehatan) of West Sumatera. A presumptive test was carried out using a lactose broth medium. Three sets of tubes were prepared, and $10 \mathrm{ml}$ of lactose broth is placed in each tube. Those three sets of tubes received $10 \mathrm{ml}, 1 \mathrm{ml}$, and $0,1 \mathrm{ml}$ refill drinking water samples using sterile pipettes. All tubes were incubated at $37^{\circ} \mathrm{C}$ for $24-48$ hours. Gas production was examined, and all positive tubes were taken for the confirmatory test to confirm coliform.

For the confirmatory test, brilliant green lactose broth (BGLB) is used as culture media. One loopful sample from each positive tubes from the presumptive test is inoculated and incubated at $37^{\circ} \mathrm{C}$ for $24-48$ hours. All the positive tubes were confirmed for the presence of coliforms. Finally, the number of bacteria present in the refill drinking water sample was determined from MPN chart.

The completed test was carried out by streaking a loopful sample from positive confirmatory tubes onto Endo's medium and incubated at $37^{\circ} \mathrm{C}$ for 24 hours. E-coli was identified with a metallic appearance in the culture medium.

\subsection{Analysis level of Cadmium, Chromium, and} Lead in water samples ${ }^{27-30}$

The level contamination of Cadmium, Chromium, and Lead in refill drinking water samples were examined using atomic absorption spectrophotometer (GBC 932 AA). This laboratory assessment was conducted at Industrial Research and Standardization Center (BARISTAND) Padang, West Sumatera. The chemicals used as the standard solution were cadmium nitrate, Chromium nitrate, and Lead nitrate.
Each standard solution was prepared with 6 levels of concentration. Then, the absorbance for each standard solution was measured using atomic absorption spectrophotometer at wavelength $228 \mathrm{~nm}$ for Cadmium, $540 \mathrm{~nm}$ for Chromium, and $293 \mathrm{~nm}$ for Lead. Calibration curves were made for each standard solution, and the correlation coefficient $\left(\mathrm{R}^{2}\right)$ was used as an evaluation for the linearity of the calibration curves. Before the measurement, every $100 \mathrm{ml}$ refill drinking water sample was mixed with concentrated nitric acid then diluted to $250 \mathrm{ml}$ with deionized water. Then the mixture was heated until the volume was reduced to about $15 \mathrm{ml}$. After cooling to room temperature, deionized water was added to $100 \mathrm{ml}$. The Cadmium, Chromium, and Lead in refill drinking water samples were determined from the absorbance measurement using atomic absorption spectrophotometer and calculated based on the regression equation of the standard solutions.

\section{Result and Discussion}

\subsection{Level of Cadmium, Chromium, and Lead Contamination}

Calibration curves for each standard solution were obtained by plotting the absorbance values from AAS instrument response with the concentration of each standard solution consisting of 6 levels of concentrations. Figure 1 shows the calibration curves of each standard solution. The regression equation and correlation coefficient $\left(\mathrm{R}^{2}\right)$ for each calibration curve were obtained statistically. The regression equation for cadmium, Chromium, and Lead are $\mathrm{y}=0.0068 \mathrm{x}-0.054 ; \mathrm{y}=0.0108 \mathrm{x}-0.0733$; and $\mathrm{y}=0.006 \mathrm{x}-0.0428$ respectively. The correlation coefficient for Cadmium, Chromium, and Lead was obtained 0.9841, 0.9934, and 0.9961, respectively. The R2 value close to 1 reveals that the concentration and absorbance have a linear relationship or are directly proportional.

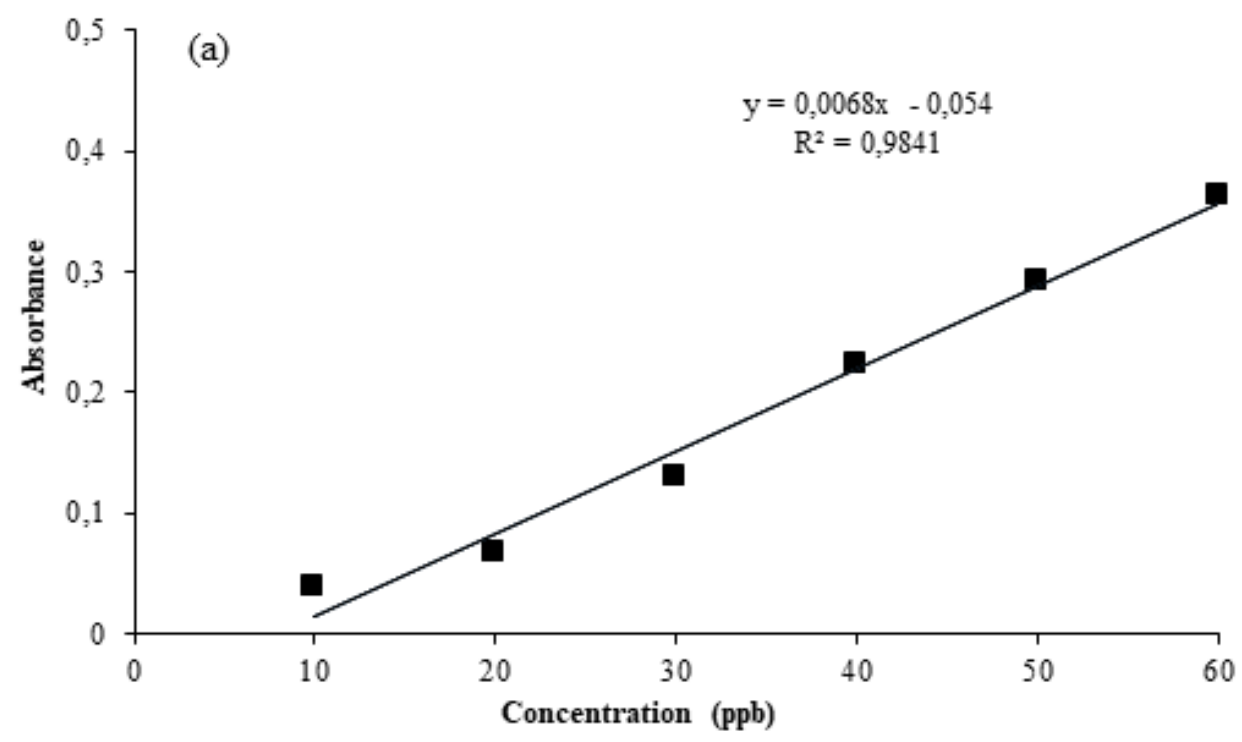



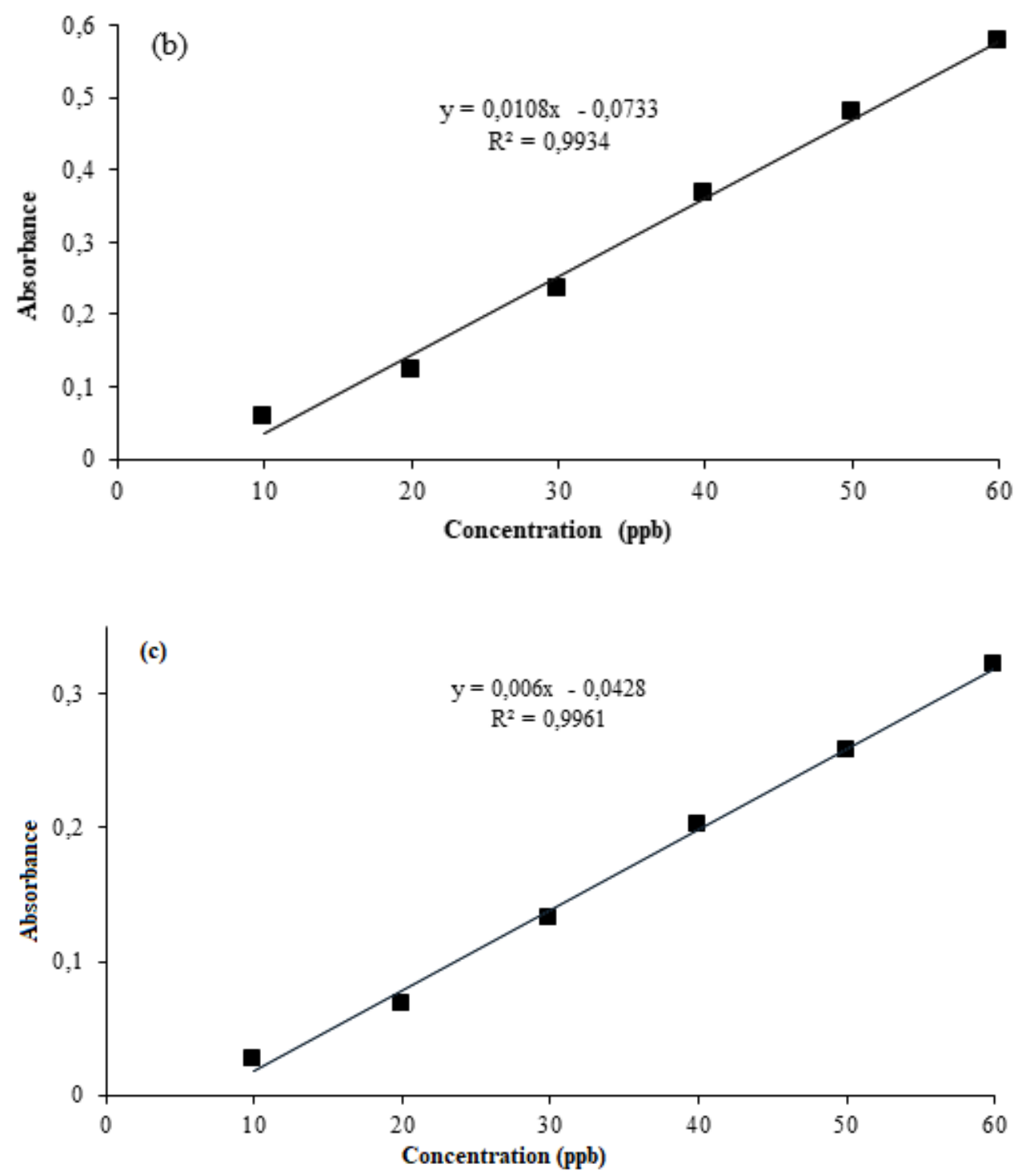

Figure 1. Calibration curves of (a) cadmium, (b) Chromium, and (c) Lead standard solutions

The average level of Cadmium, Chromium, and Lead in refill drinking water samples showed in Table 1.

Table 1. The average of Cadmium, Chromium, and Lead levels in three refill drinking water samples and the guideline values based on the regulation Number 492/Menkes/Per/IV/2010.

\begin{tabular}{|c|c|c|c|c|}
\hline $\begin{array}{c}\text { Chemical } \\
\text { Parameters } \\
\text { (ppb) }\end{array}$ & \multicolumn{3}{|c|}{ Samples } & $\begin{array}{c}\text { Guideline Values based on Ministry } \\
\text { of Health in Indonesia number } \\
\text { 492/Menkes/Per/IV/2010 } \\
\text { (ppb) }\end{array}$ \\
\cline { 2 - 4 } Chromium & 0.1427 & 0.0226 & -0.0114 & 50 \\
\hline Lead & 0.0124 & 0.367 & 0.0112 & 10 \\
\hline Cadmium & 0.0105 & -0.0017 & 0.0216 & 3 \\
\hline
\end{tabular}

Data in Table 1 showed that Chromium, Lead, and Cadmium were detected on all samples. Those three metals in drinking water originating from the source of raw water or naturally exist ${ }^{14,15}$. Several natural causes that cause the heavy metal in drinking water are geological weathering, soil erosion, metal evaporation from soil and water, and sediment resuspension ${ }^{14}$. However, Table 1 revealed that the
Chromium and Lead levels were relatively higher in specific samples compared to the Cadmium level. In the Lead case, it possibly occurs due to Lead's leaching from the pipe that distributes the water. Several studies reported that one of the most common Lead sources in drinking water is plumbing fixtures ${ }^{31,32}$. In this study, the raw drinking water sources of three DWRS in Bungus Teluk Babung are from 
springs in the hilly side of bungus and distribute using the pipe to the DWRS.

Chromium's presence, which is also relatively high in sample A probably causes by natural sources due to the spring's water as the raw water source. Chromium is reported found naturally on the earth's crust, and the presence of Chromium in drinking water also results from industrialization, rapid urbanization, over-dependency on fossil fuels, industrial and agricultural wastes, domestic effluents, and mining 20,23. It is consistent with the location of Bungus Teluk Kabung as an industrial, agricultural, and port area.

However, none of those samples contain the level above the safe limits based on the guideline values recommended by the Ministry of Health in Indonesia. Each Chromium, Lead, and Cadmium value in those samples was much lower than the permissible limit. But it still needs regular assessment to ensure the water quality of refill drinking water in the future.

\subsection{Microbial Assessment}

Assessment of microbial contamination was performed on the 3 refill drinking water samples. The first step is a presumptive test using lactose broth medium, and the results showed all samples giving positive reaction proved by gas production in a dirham tube. It reveals that all water samples are contaminated microbiologically and need further testing. The next step is a confirmatory test using BGLB medium to confirm the presence of coliform. The total coliform presence in each sample is shown in Table 2.

Table 2. MPN of refill drinking water samples.

\begin{tabular}{|c|c|c|c|c|}
\hline \multirow{2}{*}{ Sample } & \multicolumn{3}{|c|}{ Dilution level } & \multirow{2}{*}{$\begin{array}{c}\text { MPN } \\
(\text { per } 100 \mathrm{ml})\end{array}$} \\
\hline & $10 \mathrm{ml}$ & $1 \mathrm{ml}$ & $0,1 \mathrm{ml}$ & \\
\hline A & 2 & 2 & 1 & 28 \\
\hline B & 2 & 1 & 0 & 15 \\
\hline $\mathrm{C}$ & 3 & 3 & 0 & 240 \\
\hline
\end{tabular}

Based on the data in Table 2, all refill drinking water samples show the MPN value exceeds the Minister of Health of Indonesia standard limit of $0 / 100 \mathrm{ml}$. The highest coliform count from those 3 samples of refill drinking water was observed in sample $\mathrm{C}$ with 240 MPN per $100 \mathrm{ml}$. The total coliform of samples $\mathrm{A}$ and $\mathrm{B}$ were $28 \mathrm{MPN}$ per $100 \mathrm{ml}$ and $15 \mathrm{MPN}$ per $100 \mathrm{ml}$, respectively. Based on risk categories of contamination, samples $\mathrm{A}$ and $\mathrm{B}$ belong to intermediate-risk, and sample $\mathrm{C}$ belongs to high-risk category. A further test was completed test to measure the growth of Escherichia coli on endo's medium. The presence of Escherichia coli was confirmed with a metallic sheen for all samples. It revealed that refill drinking water from three DWRS could cause a health risk for consumers. This is still in line with the results reported by Wandrivel et al. in 2012. It was reported that all samples from the source of the spring in the hilly side of Bungus Teluk Kabung were contaminated by coliform ${ }^{7}$. Another study said microbial contamination might be caused by the contaminated raw water source, ineffective water treatment process, and recontamination during distribution. Moreover, springs and almost all unprotected springs are contaminated by coliform bacteria $^{33}$.

\section{Conclusions}

This study indicated that the level of Cadmium, Chromium, and Lead in refill drinking water samples were below the permissible limit of the regulation on Minister of Health Republic of Indonesia number
492/Menkes/Per/IV/2010. The highest amount is Lead, with the value $0.367 \mathrm{ppb}$, and it much lower than $10 \mathrm{ppb}$ as the maximum guideline value. The microbial testing showed coliform bacteria and E. coli contaminated all samples. Total coliform for each sample is 28,15 , and $240 \mathrm{MPN} / 100 \mathrm{ml}$. It reveals that all samples from 3 different depots in Bungus Teluk Kabung did not meet the health requirements and could harm human health. Contamination possibly occurs from raw water and during the distribution to drinking water refilling stations. The health authority must do a periodic audit and advise each owner of drinking water refilling stations to maintain the quality of drinking water.

\section{References}

1- L. C. Sima, M. Elimelech, More than a drop in the bucket: decentralized membrane-based drinking water refill stations in southeast Asia, Environ. Sci. Technol., 2013, 47, 7580-7588.

2- W. Kusmawati, L. Rahayu, Contamination of Escherichia coli Drinking Water Refills on Drinking Water Depots in Malang City, Biogenesis, 2019, 7, 9-13.

3- E. Apriliana, M. R. Ramadhian, M. Gapila, Bakteriological Quality Of Refill Drinking Water At Refill Drinking Water Depots In Bandar Lampung, JUKE., 2014, 4, 142-146.

4- Ministry of Health Republic of Indonesia: Regulation Number 492/MENKES/PER/IV/2010 about Guideline for Drinking Water Quality, 2010. 
5- WHO, Guidelines for Drinking Water Quality: Third Edition, Incorporating the First and Second Addenda, Recommendations, World Health Organization, Geneva, 2008.

6- Ministry of Health Republic of Indonesia: Regulation Number 43 about Hygiene and Sanitation of Refill Water Station, Jakarta, Indonesia, 2014.

7- R. Wandrivel, N. Suharti, Y. Lestari, Kualitas Air Minum Yang Diproduksi Depot Air Minum Isi Ulang Di Kecamatan Bungus Padang Berdasarkan Persyaratan Mikrobiologi, Jurnal Kesehatan Andalas, 2012, 1, 129-133.

8- A. Khoeriyah, Anies, Aspek Kualitas bakteriologis depot air minum isi ulang (DAMIU) di Kabupaten Bandung Barat, Majalah Kedokteran Bandung, 2015, 47, 137-144.

9- R. A. Dewanti, L. Sulistyorini, Analisis Kualitas Bakteriologis Air Minum Isi Ulang Di Kelurahan Sememi, Kecamatan Benowo, The Indonesian Journal of Public Health, 2017, 12 , 39-50.

10-R. S. Pakpahan, I. Picauly, I. N. W. Mahayasa, Escherichia coli Microbial and Total Coliform Bacterial Contamination of Refill Drinking Water, Kesmas: Jurnal Kesehatan Masyarakat Nasional, 2015, 9, 300-307.

11-A. G. Bambang, Fatimawali, N. S. Kojong, Analisis Cemaran Bakteri Coliform Dan Identifikasi Escherichia Coli Pada Air Isi Ulang Dari Depot Di Kota Manado, PHARMACON : Jurnal Ilmiah Farmasi, 2014, 3, 325-334.

12-N. A. Ismayanti, F. Kesumaningrum, Muhaimin, Analisis Kadar Logam Fe, Cr, Cd dan Pb dalam Air Minum Isi Ulang Di Lingkungan Sekitar Kampus Universitas Islam Indonesia Yogyakarta Menggunakan Spektrofotometer Serapan Atom (SSA), Ind. J. Chem. Anal., 2019, 2, 41-46.

13-S. Bali, Kandungan Logam Berat (Timbal, Kadmium), Amoniak, Nitrit Dalam Air Minum Isi Ulang Di Pekanbaru, Health Care, 2012, 2, $1-4$.

14-J. Briffa, E. Sinagra, R. Blundell, Heavy metal pollution in the environment and their toxicological effects on humans, Heliyon, 2020, 6, e04691.

15-S. Chowdhury, M. A. J. Mazumder, O. Al-Attas, T. Husain, Heavy metals in drinking water: Occurrences, implications, and future needs in developing countries, Science of the Total Environment, 2016, 569, 476-488.

16-A. Bernard, Cadmium \& its adverse effects on human health, Indian Journal of Medical Research, 2008, 128, 557-564.

17-G. Genchi, M. S. Sinicropi, G. Lauria, A. Carocci, A. Catalano, The Effects of Cadmium Toxicity, International journal of environmental research and public health, 2020, 17, 3782 .

18- A. Moldovan, M. A. Hoaghia, E. Kovacs, Ionut, C. Mirea, M. Kenesz, R. A. Arghir, A. Petculescu, E. A. Levei, O. T. Moldovan, Quality and Health Risk Assessment Associated with Water Consumption-A Case Study on Karstic Springs, Water, 2020, 12, 3510.

19-P. Massányi, M. Massányi, R. Madeddu, R. Stawarz, N. Lukáč, Effects of Cadmium, Lead, and Mercury on the Structure and Function of Reproductive Organs, Toxics, 2020, 8, 94.

20-WHO, Guidelines for Drinking Water Quality: Chromium in drinking water, World Health Organization, Geneva, 1996.

21-A. Chiu, X. L. Shi, W. K. Lee, R. Hill, T. P. Wakeman, A. Katz, B. Xu, N. S. Dalal, J. D. Robertson, C. Chen, N. Chiu, L. Donehower, Review of Chromium (VI) apoptosis, cell-cyclearrest, and carcinogenesis, J. Environ Sci. Health C. Environ. Carcinog. Ecotoxicol Rev., 2010, 28, 188-230.

22-R. Shrivastava, R. K. Upreti, P. K. Seth, U. C. Chaturvedi, Effects of Chromium on the immune system, FEMS Immunology and Medical Microbiology, 2002, 34, 1-7.

23-A. Zhitkovich, Chromium in Drinking Water: Sources, Metabolism, and Cancer Risks, Chem. Res. Toxicol., 2011, 24, 1617-1629.

24- Y. Yulius, H. Prihatno, I. R. Suhelmi, Pola spasial kedalaman perairan di Teluk Bungus, kota Padang, Prosiding PIT VII ISOI 2010, 2010, 205-212.

25-A. Putra, D. Hermon, W. Novarino, T. A. Tanto, Suitability of the spatial utilization on special zone (port) in the coastal region of bungus bay padang city, Jurnal kelautan Nasional, 2020, 15, 91-102.

26-Departement Kesehatan RI, Petunjuk Pemeriksaan Bakteriologi Air, Pusat Laboratorium Kesehatan Departemen Kesehatan Republik Indonesia, Jakarta, 2000.

27-J. M. Willey, L. M. Sherwood, C. J. Woolverton, Prescott, Harley, and Klein's, Microbiology, New York: Mc Graw Hill, 2008, 272.

28-Badan Standar Nasional, Cara Uji Cd dengan Spektrofotometri Serapan Atom (SSA), SNI 06-6989.16-2004.

29-Badan Standar Nasional, Cara Uji Cr dengan Spektrofotometri Serapan Atom (SSA), SNI 06-6989.17-2004.

30-Badan Standar Nasional, Cara Uji Pb dengan Spektrofotometri Serapan Atom (SSA), SNI 06-6989.8-2004.

31-WHO, Guidelines for Drinking Water Quality: Lead in drinking water, World Health Organization, 2011.

32-Y. Zhang, Y. P. Lin, Leaching of Lead from new unplasticized polyvinyl chloride (uPVC) pipes into drinking water, Environ. Sci. Pollut. Res., 2014, 22, 8405-8411.

33-S. Y. I. Sari, D. K. Sunjaya, H. S. Furusawa, C. Watanabe, A. S. Raksanagara, Water Sources Quality in Urban Slum Settlement along the Contaminated River Basin in Indonesia: Application of Quantitative Microbial Risk Assessment, Journal of Environmental and Public Health, 2018, 1-7 